\title{
Pengaruh Program Latihan Olahraga dan Edukasi Gizi Terhadap Komposisi Tubuh, Lingkar Perut dan Lingkar Panggul pada Wanita Usia Produktif di Depok
}

\section{The Effect of Sport Training Program and Nutrition Education on Body Composition, Abdominal Circumferences and Hip Circumferences in Productive Age Women in Depok}

\author{
Amelia Avissa ${ }^{1}$, Mury Kuswari ${ }^{2}$, Rachmanida Nuzrina ${ }^{3}$, Nazhif Gifari ${ }^{4}$, Vitria Melani ${ }^{5}$ \\ 1,2,3,4,5Fakultas IImu-IImu Kesehatan, Universitas Esa Unggul Jakarta Barat \\ email: amelia.avissa.aa@gmail.com¹, mury@esaunggul.ac.id², \\ rachmanida.nuzrina@esaunggul.ac.id ${ }^{3}$, nazhif.gifari@esaunggul.ac.id ${ }^{4}$, \\ vitria@esaunggul.ac.id 5 \\ do \\ https://doi.org/10.20884/1.paju.2021.2.2.3947
}

\begin{abstract}
Abstrak
Data prevalensi obesitas di seluruh dunia meningkat dua kali lipat antara tahun 1980 dan 2014. Meningkatnya obesitas tidak lepas dari gaya hidup, seperti menurunnya aktivitas fisik. Edukasi gizi baik melalui penyuluhan, konseling ataupun berbagai metode lainnya merupakan salah satu upaya yang dapat dilakukan dalam mencegah masalah gizi. Program latihan olahraga dan edukasi gizi adalah cara yang tepat untuk melihat seberapa besar pengaruh terhadap status gizi di pusat kebugaran khusus wanita seperti di Duadua Studio Depok. Tujuan penelitian ini adalah mengetahui pengaruh program latihan olahraga dan edukasi gizi terhadap komposisi tubuh, lingkar perut dan lingkar panggul pada peserta olahraga di pusat kebugaran Duadua Studio Depok. Penelitian ini menggunakan desain One Group Pretest-Posttest. Teknik pengambilan sampel yang digunakan adalah teknik longitudinal dengan sampel berjumlah 34 orang. Analisis data menggunakan Uji t-paired. Hasil penelitian menunjukkan ada pengaruh yang signifikan dari program latihan olahraga dan edukasi gizi terhadap komposisi tubuh dan lingkar perut $(p<0,05)$. Namun, tidak terdapat pengaruh yang signifikan terhadap lingkar panggul $(p>0,05)$. Terdapat pengaruh program latihan olahraga dan edukasi gizi terhadap komposisi tubuh dan lingkar perut. Tidak terdapat pengaruh yang signifikan terhadap lingkar panggul pada peserta olahraga di pusat kebugaran di Duadua Studio Depok. Pada penelitian selanjutnya perlu menggunakan kelompok perlakuan dan kelompok kontrol, hal tersebut dapat menjadikan kelompok pembanding pada saat penelitian.
\end{abstract}

Kata Kunci: Edukasi Gizi, Komposisi Tubuh, Lingkar Panggul, Lingkar Perut, Obesitas, Program Latihan

\section{Abstract}

Worldwide, obesity prevalence data has doubled between 1980 and 2014. Increased obesity is inseparable from lifestyle, for example decreased physical activity. Nutrition education through counseling or other methods is one of the efforts that can be done to prevent nutritional problems. The exercise and

Alamat Koresponden : Fakultas IImu-IImu Kesehatan, Universitas Esa Unggul Jakarta Barat Email : mury@esaunggul.ac.id

\section{(c)}

Jurnal Physical Activity Journal (PAJU) This work is licensed under a Creative Commons Attribution 4.0 International License. 
nutrition education programs are used to see how much that influenced the participants' nutritional status in the women-only fitness center like in Duadua Studio Depok. Objective: Knowing the effect of exercise and nutrition education programs on the body composition, waist circumference and hip circumference at Fitness Center Participants in Duadua Studio Depok. Methods: This study used the design of One Groups Pretest-Posttest. The sampling technique used is a longitudinal technique, namely data retrieval is done repeatedly several times at different times with a sample of 34 people. Data analysis using t-paired test. Results: The results showed that there was a significant effect of exercise and nutrition education programs on body composition $(p<0.05)$ and waist circumference $(p<0.05)$. However, there was no significant effect on hip circumference $(p>0.05)$. Conclusion: There is the influence of exercise and nutrition education programs on body composition and waist circumference. However, there was no significant effect on hip circumference at fitness center participants in Duadua Studio Depok. Suggestion: The next researcher needs to use the treatment group and the control group as a comparison.

Keywords : Body Composition, Exercise Program, Hip Circumference, Nutrition Education, Obesity, Waist Circumference.

\section{PENDAHULUAN}

Perkembangan IImu Pengetahuan dan Teknologi (IPTEK) yang meningkat secara pesat dari tahun ke tahun membuat hidup manusia lebih nyaman. Kemudahan dan efektivitas waktu dapat dirasakan oleh semua orang seperti kemudahan transportasi dan berkomunikasi. Kemudahan aksesibilitas terhadap hal-hal tersebut tentu memiliki efek positif terhadap kemajuan teknologi. Meski begitu, patut diperhatikan bahwa kemudahan dan kecanggihan dari teknologi juga memiliki dampak negtif terhadap kehidupan manusia, seperti berkurangnya aktivitas fisik. Saat ini, hampir semua orang menggunakan moda transportasi canggih, dan jarang menggunakan moda transportasi tradisional seperti sepeda atau bahkan berjalan kaki. Hal ini menimbulkan kurangnya aktivitas fisik sehari-hari sehingga menimbulkan pengaruh terhadap masalah gizi dan kesehatan (Hanifah, 2015).

Saat ini, masalah obesitas adalah masalah global yang mempengaruhi masyarakat dunia baik di negara berkembang maupun di negara maju, termasuk Indonesia. Obesitas adalah kondisi ketika perbandingan antara berat badan dan tinggi badan melebihi standar tertentu. Obesitas adalah kondisi persentase lemak tubuh $>20 \%$ pada laki-laki dan $>25 \%$ pada perempuan (Barret et al., 2014). Meningkatnya obesitas tidak bisa terlepas dari gaya hidup, seperti aktivitas fisik kurang. Faktor genetik juga menentukan mekanisme kontrol berat badan melalui pengaruh hormonal dan syaraf (Limanan, 2013).

Berdasarkan data World Health Organization (WHO), pada 2014, lebih dari1.9 milyar orang dewasa berumur 18 tahun keatas mengalami kelebihan berat badan. Lebih dari 600 juta orang 
Amelia Avissa, Mury Kuswari, Rachmanida Nuzrina, Nazhif Gifari \& Vitria Melani | Pengaruh Program Latihan Olahraga dan Edukasi Gizi Terhadap Komposisi Tubuh, Lingkar Perut dan Lingkar Panggul pada Wanita Usia Produktif di Depok

pada populasi ini mengalami obesitas. Secara keseluruhan, sekitar $13 \%$ dari populasi orang dewasa (11\% laki-laki dan 15\% perempuan) mengalami obesitas pada 2014. Prevalensi obesitas di seluruh dunia telah meningkat sebanyak 2 kali lipat antara tahun 1980 hingga 2014 (WHO, 2015). Lebih dari 200 juta pria dewasa mengalami obesitas (Indeks Massa Tubuh $\geq 30 \mathrm{~kg} / \mathrm{m}^{2}$ ), namun jumlah wanita yang mengalami obesitas lebih besar yaitu sekitar 300 juta jiwa. Secara global tingkat obesitas telah lebih dari dua kali lipat sejak tahun 1980 dari $5 \%$ menjadi 10\% pada pria dan $8 \%$ sampai $14 \%$ pada wanita (WHO 2011).

Komposisi tubuh dideskripsikan sebagai persentase bagian tubuh seperti persentase massa tulang, air, otot dan lemak. Bagian dari tubuh terdiri dari adiposa dan massa tubuh tanpa lemak (Forbes, 2000). Beberapa hasil pengukuran lingkar tubuh juga dapat diimplikasikan sebagai banyaknya lemak dalam tubuh. Lingkar tubuh yang perlu diukur meliputi lingkar perut dan lingkar panggul. Pengukuran komposisi tubuh juga dimaksudkan untuk mendeteksi kebutuhan tubuh terhadap asupan makanan dan memperoleh informasi yang relevan terhadap pencegahan dan penanganan penyakit.

Olahraga merupakan aktivitas yang dapat dilakukan untuk menjaga tubuh agar tetap sehat, bugar, dan ideal. Latihan olahraga aerobik adalah jenis latihan paling mudah, murah, dan memberikan banyak manfaaat kesehatan pada tubuh, terutama bagi kesehatan jantung dan paruparu. Manfaat dari latihan aerobik adalah meningkatkan kebugaran tubuh dan meningkatkan pembakaran lemak tubuh sehingga tubuh tetap ideal. Latihan paling efektif untuk menurunkan berat badan adalah latihan aerobik yang berlangsnug selama 20 hingga 60 menit. Beberapa jenis olahraga yang termasuk olahraga aerobik adalah jogging, bersepeda, berenang, dan senam aerobik (Suharjana, 2013).

Pendampingan gizi baik melalui konseling maupun metode lainnya adalah salah satu upaya yang dapat dilakukan untuk mencegah masalah gizi. Pendidikan gizi dan pendampingan gizi memberikan hasil berupa peningkatan pengetahuan, kesadaran gizi, dan perubahan perilaku untuk mencapai kondisi gizi dan kesehatan yang optimal (Nurmasyita, Widjanarko dan Margawati, 2016). Hal ini secara lebih lanjut akan memengaruhi perilaku seseorang dalam mengonsumsi pangan sebagai sumber zat gizi dengan cara mengikuti panduan pola makan dan kebutuhan tubuh (Silalahi, Aritonang dan Ashar, 2016). Pengetahuan atau fungsi kognitif adalah daerah yang sangat penting untuk pembentukan tindakan seseorang.

Kebutuhan gizi sehari-hari untuk setiap orang berbeda-beda. Gizi yang cukup sangatlah penting dalam mencapai kebugaran fisik dan status gizi yang baik. Status gizi adalah hasil dari kondisi keseimbangan dalam bentuk variabel tertentu atau dapat dikatakan bahwa status gizi adalah indikator baik-buruknya asupan makanan sehari-hari. Status gizi yang baik dibutuhkan untuk menjaga derajat kesehatan dan kebugaran (Amanda, Nisa dan Tiwuk, 2015). 
Perkembangan olahraga aerobik sudah sedemikian baik, terutama senam aerobik yang sangat menarik perhatian ibu dan remaja perempuan baik di kota besar maupun kota kecil. Senam aeronbik adalah jenis latihan olahraga yang diiringi musik dan digunakan untuk penurunan berat badan serta sarana rehabilitasi dan terapi yang efektif. Terdapat beberapa manfaat yang dapat diperoleh dari aktivitas ini, seperti peningkatan kerja jantung, peningkatan kekuatan otot, pembakaran lemak, dan berbagai manfaat lainnya. Program latihan olahraga dan pendidikan gizi digunakan untuk melihat seberapa besar pengaruhnya terhadap gaya hidup sehat diberbagai pusat kebugaran seperti di Duadua Studio Depok. Duadua Studio Depok adalah pusat kebugaran khusus wanita yang menyediakan kelas olahraga yang cocok bagi wanita, seperti yoga, zumba, pilloxing, pound fit, muaythai dan area kebugaran kardio serta konsultasi gizi yang dapat mengoptimasi gaya hidup sehat dari peserta olahraga.

Berdasarkan latar belakang yang disebutkan diatas, peneliti tertarik untuk melakukan penelitian mengenai Pengaruh Program Latihan Olahraga dan Edukasi Gizi Terhadap Komposisi Tubuh, Lingkar Perut dan Lingkar Panggul pada Wanita Usia Produktif di Depok. Tujuan dari penelitian ini adalah untuk menentukan efek dari program latihan olahraga dan pendidikan gizi terhadap komposisi tubuh, lingkar perut, dan lingkar panggul dari peserta latihan olahraga pada wanita usia produktif di Depok.

\section{METODE}

Rancangan yang dipakai dalam penelitian ini adalah desain kuasi-eksperimental, onegroup-pre-post-test. Penelitian ini dilakukan di pusat kebugaran Duadua Studio Depok selama 9 minggu. Intervensi yang diberikan berupa program latihan dan pendidikan gizi pada peserta kelas olahraga di Duadua Studio Depok. Teknik pengambilan sampel yang digunakan adalah total sampling dengan kriteria inklusi dan eksklusi. Kriteria inklusi meliputi: 1) Peserta kelas olahraga yang merupakan anggota aktif di Duadua Studio Depok, yang dianggap aktif bila mengikuti kelas olahraga minimal satu kali setiap minggunya; 2) Peserta bersedia mengikuti penelitian; 3) Peserta tidak sedang ikut dalam penelitian lainnya dan 4) Peserta berumur 18 hingga 49 tahun. Kriteria eksklusi meliputi: 1) Peserta satu kali atau lebih tidak hadir sampai penelitian selesai dan 2) Peserta mengalami cedera. Populasi penelitian ini adalah peserta kelas olahraga di pusat kebugaran Duadua Studio Depok, dengan jumlah total populasi sebanyak 112 perempuan dewasa. Setelah kriteria inklusi dan eksklusi dimasukkan, 42 peserta olahraga diambil menjadi sampel penelitian.

Data yang diambil dalam penelitian ini adalah jenis data primer yang secara langsung diambil oleh peneliti dan data sekunder yang diperoleh dari Duadua Studio Depok. Data primer dikumpulkan dengan cara mengisi kuesioner yang telah diuji validitas dan reliabilitasnya sehingga 
Amelia Avissa, Mury Kuswari, Rachmanida Nuzrina, Nazhif Gifari \& Vitria Melani | Pengaruh Program Latihan Olahraga dan Edukasi Gizi Terhadap Komposisi Tubuh, Lingkar Perut dan Lingkar Panggul pada Wanita Usia Produktif di Depok

kuesioner tersebut dapat digunakan sebagai instrumen pengukuran dalam penelitian ini. Kehadiran dilihat dari absensi sedangkan berat badan, tinggi badan, komposisi tubuh, lingkar perut dan lingkar panggul diukur setiap 2 minggu selama 9 minggu. Edukasi gizi yang diberikan terdiri dari 2 sesi konseling dalam jangka waktu yang sama dan mini konseling diadakan setiap kali pengukuran. Data sekunder diperoleh dari profil pusat kebugaran Duadaua Depok Studio.

Analisis data dari penelitian ini adalah analisis univariat yang menggunakan rataan bila data terdistribusi normal atau median jika data terdistribusi tidak normal. Analisis bivariat digunakan untuk mengetahui perbedaan variabel independen dan variabel dependen. Uji beda $t$ test berpasangan kemudian digunakan apabila data terdistribusi normal atau menggunakan uji Wilcoxon bila data terdistribusi tidak normal.

\section{HASIL}

Duadua Studio Depok adalah salah satu pusat kebugaran khusus perempuan terbesar di Depok yang menyediakan berbagai kelas olahraga yang cocok untuk segala kalangan, seperti yoga, zumba, pilloxing, pound fit, Muaythai, dan area kebugaran kardio. Dua dua Studio memiliki sebelas instruktur kebugaran yang terbagi menjadi setiap masing-masing bidang. Pusat kebugaran ini buka mulai dari hari Senin hingga Jumat mulai pukul 08.00 hingga 20.00 WIB, dan pada hari Sabtu hingga minggu pukul 08.00 hingga 13.00 WIB. Terdapat dua orang pegawai di tempat ini. Fasilitas yang dimiliki tempat ini selain ruang senam antara lain ruang kebugaran kardio, ruang ganti dan ruang loker, kamar mandi, musholla, dan kantor.

Data karakteristik responden digunakan untuk menentukan keragaman responden berdasarkan umur, pendidikan terakhir, pekerjaan, dan kelompok program. Hal ini dapat digunakan untuk menggambarkan kondisi responden dan hubungannya dengan masalah penelitian dan tujuan penelitian secara cukup jelas. Karakteristik responden dapat dilihat pada tabel 1. dibawah ini.

Tabel 1. Karakteristik Responden

\begin{tabular}{lll}
\hline \multicolumn{1}{c}{ Variabel } & \multicolumn{2}{c}{ Total } \\
& N & \multicolumn{1}{c}{$\%$} \\
\hline Umur & & \\
Remaja Akhir (17 - 25 tahun) & 7 & 20.59 \\
Dewasa Awal (26 - 35 tahun) & 14 & 41.18 \\
Dewasa Akhir (36 - 45 tahun) & 12 & 35.29 \\
Lansia Awal (46 - 55 tahun) & 1 & 2.94 \\
\hline Total & 34 & 100 \\
\hline Pekerjaan & & \\
lbu Rumah Tangga & 12 & 35.29 \\
Mahasiswa & 1 & 2.94 \\
PNS & 2 & 5.88 \\
Pegawai Swasta & 12 & 35.29 \\
Guru & 2 & 5.88 \\
Wirausaha & 4 & 11.76
\end{tabular}




\begin{tabular}{lll} 
Tidak Bekerja & 1 & 2.94 \\
\hline Total & 34 & 100 \\
\hline Pendidikan Terakhir & & \\
Pendidikan Tinggi & 30 & 88.24 \\
SMA & 4 & 11.76 \\
\hline Total & 34 & 100 \\
\hline Kelompok Program & & \\
$\quad$ High Impact & 19 & 55.9 \\
Low + High Impact & 15 & 44.1 \\
\hline$\quad$ Total & 34 & 100
\end{tabular}

Berdasarkan karakteristik umur responden di tabel 1, sebagian besar responden berusia 26-35 tahun atau dewasa awal sebanyak 14 orang. Terdapat juga satu subjek yang tergolong remaja akhir dan lansia awal. Berdasarkan karakteristik pekerjaan, sebagian besar responden memiliki pekerjaan yaitu sebanyak 22 orang. Terdapat satu orang yang masih mahasiswa dan satu orang yang tidak bekerja maupun menjadi ibu rumah tangga. Responden memiliki pendidikan terakhir berupa pendidikan tinggi (Universitas/Diploma) yaitu sebanyak 30 orang dan hanya 4 orang yang memiliki pendidikan terakhir SMA.

Jenis dari latihan aerobik yang ada di Duadua Studio Depok terdiri dari kelas low impact seperti yoga dan pound fit serta high impact seperti muaythai, zumba, pilloxing dan strong by zumba. Program dikelompokkan menjadi high impact saja serta kombinasi low dan high impact, dengan kebebasan responden untuk memilih jenis kelompok program apa yang akan diikuti.

\section{Komposisi Tubuh}

Komposisi tubuh akan berubah seiring bertambahnya umur, mulai dari embrio hingga dewasa. Kecepatan pertumbuhan atau pertambahan berat badan sangatlah berpengaruh terhadap proporsi dari setiap aspek komposisi tubuh. Komposisi tubuh diukur untuk mengetahui persentase lemak dan massa otot tubuh.

a. Persentase Lemak Tubuh

Rata-rata persentase lemak tubuh subjek, seperti yang ditunjukkan gambar 1 berkurang sebanyak $0.47 \%$ dari pengukuran pertama yaitu $36.26 \%$ menjadi $35.79 \%$ pada minggu kelima.

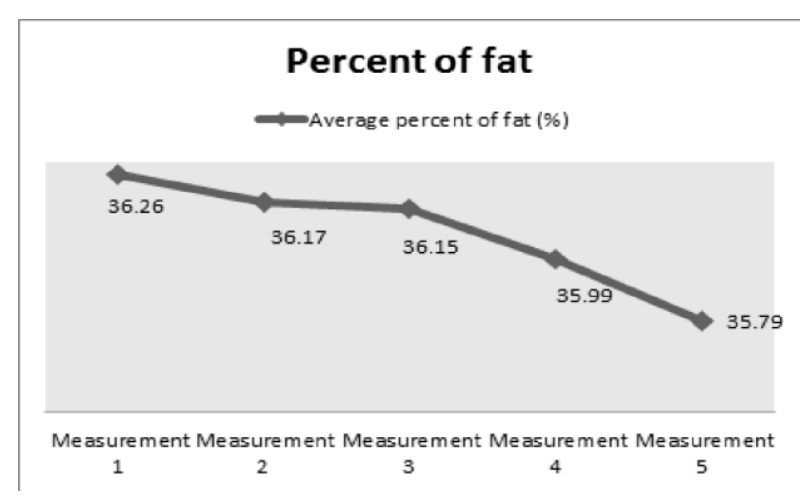

Gambar 1. Rata-Rata Persentase Lemak Tubuh 
Amelia Avissa, Mury Kuswari, Rachmanida Nuzrina, Nazhif Gifari \& Vitria Melani | Pengaruh Program Latihan Olahraga dan Edukasi Gizi Terhadap Komposisi Tubuh, Lingkar Perut dan Lingkar Panggul pada Wanita Usia Produktif di Depok

\section{b. Massa otot}

Rata-rata persentase massa otot tubuh meningkat sebanyak $0.39 \%$ setelah intervensi selama sembilan minggu, dari $31.31 \%$ menjadi $31.7 \%$ pada pengukuran kelima.

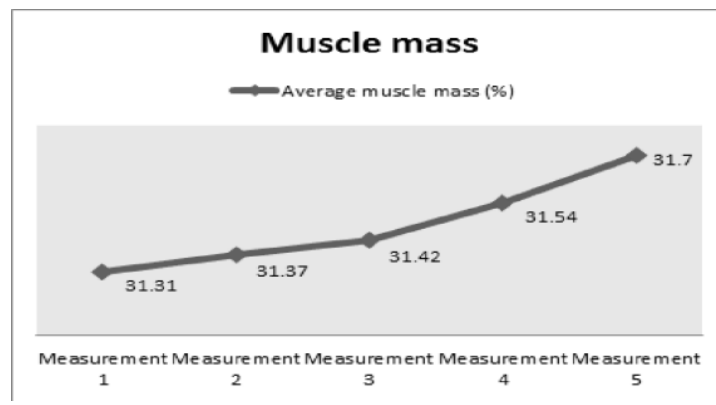

Gambar 2. Rata-rata persentase otot tubuh

\section{Lingkar Perut}

Gambar 3 menunjukkan rata-rata lingkar perut selama pengukuran sebanyak 5 kali dalam 9 minggu intervensi. Rata-rata panjang lingkar perut responden menurun sebanyak $0.62 \mathrm{~cm}$ mulai dari $83.43 \mathrm{~cm}$ pada awal intervensi menjadi $82.81 \mathrm{~cm}$ pada akhir intervensi.

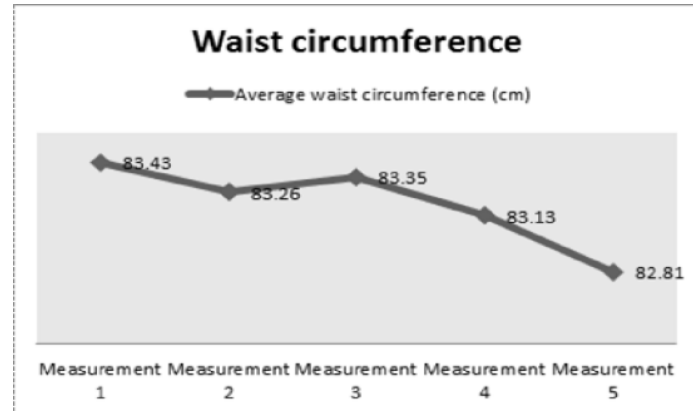

Gambar 3. Rata-rata panjang lingkar perut responden.

\section{Lingkar Pinggul}

Gambar 4 menunjukkan rata-rata lingkar pinggul responden pada 5 kali pengukuran selama 9 minggu. Rata-rata lingkar pinggul responden menurun sebanyak $0.06 \mathrm{~cm}$, dari $100.66 \mathrm{~cm}$ pada pengukuran pertama menjadi $100.60 \mathrm{~cm}$ pada pengukuran kelima.

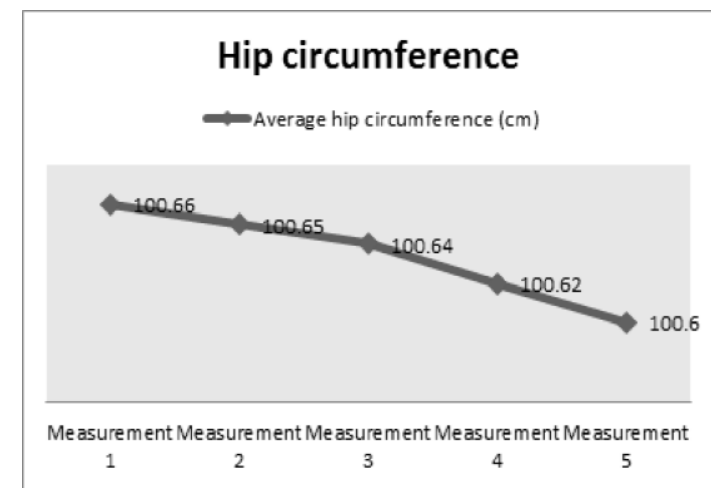

Gambar 4. Rata-rata lingkar pinggul 


\section{Efek dari Intervensi terhadap Komposisi Tubuh}

a. Massa Lemak Tubuh

Berdasarkan tabel 2 dapat dilihat bahwa rata-rata persentase lemak responden sebelum intervensi adalah $36.26 \pm 5.70 \%$. Setelah intervensi, rata-rata massa lemak responden adalah $35.79 \pm 12.33 \%$. Analisis menggunak uji paired t-test menunjukkan bahwa terdapat penurunan persentase massa lemak secara signifikan $(p=0.0001)$ karena intervensi sebanyak $0.47 \%$.

Tabel 2. Analisis Efek Intervensi Terhadap Persentase Lemak Tubuh Responden

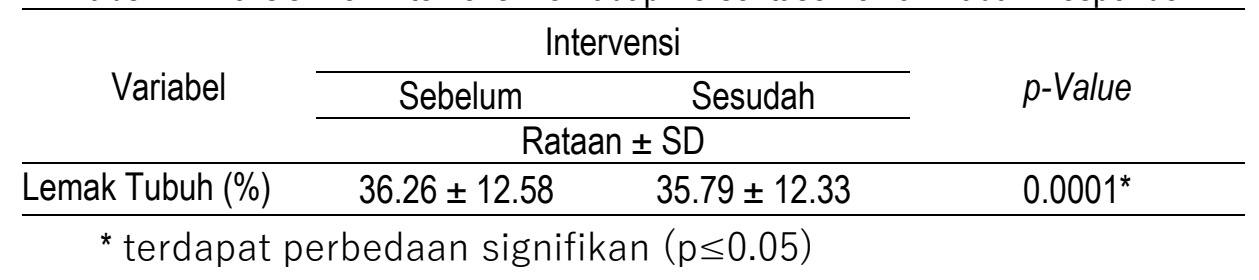

b. Massa Otot Tubuh

Berdasarkan tabel 3, rata-rata persentase massa otot responden sebelum responden adalah $31.31 \pm 5.70 \%$. Setelah intervensi hasil ini meningkat sebanyak $0.39 \%$ menjadi $31.70 \pm 5.55 \%$. Uji paired t-test menunjukkan bahwa terdapat peningkatan signifikan karena intervensi $(p=0.0001)$.

Tabel 3. Analisis Efek Intervensi Terhadap Persentase Massa Otot Tubuh Responden

\begin{tabular}{|c|c|c|c|}
\hline \multirow{3}{*}{ Variabel } & & & \multirow{2}{*}{$p$-Value } \\
\hline & Sebelum & Sesudah & \\
\hline & \multicolumn{2}{|c|}{ Rataan \pm SD } & \\
\hline Massa otot (\%) & $31.31 \pm 5.70$ & $31.70 \pm 5.55$ & $0.0001^{\star}$ \\
\hline
\end{tabular}

\section{Efek dari Intervensi Terhadap Lingkar Perut}

Berdasarkan tabel 4 rata-rata lingkar perut responden adalah $83.43 \pm 13.33 \mathrm{~cm}$. Hasil ini menurun sebanyak $0.62 \mathrm{~cm}$ menjadi $82.81 \pm 0.99 \mathrm{~cm}$. Uji paired t-test menunjukkan bahwa terdapat penurunan signifikan terhadap lingkar perut akibat intervensi $(p=0.0001)$ olahraga aerobik dan pendidikan gizi.

Tabel 4. Analisis Efek Intervensi Terhadap Lingkar Perut

\begin{tabular}{|c|c|c|c|}
\hline \multirow{3}{*}{ Variabel } & $\ln$ & & \multirow{3}{*}{$p$-Value } \\
\hline & Sebelum & Sesudah & \\
\hline & \multicolumn{2}{|c|}{ Rataan \pm SD } & \\
\hline Lingkar Perut (cm) & $83.43 \pm 13.33$ & $82.81 \pm 13.20$ & $0.0001^{*}$ \\
\hline
\end{tabular}

\section{Efek dari Intervensi Terhadap Lingkar Pinggul}

Tabel 5 menunjukkan bahwa rata-rata lingkar pinggul responden sebelum intervensi adalah $100.66 \pm 9.53 \mathrm{~cm}$, kemudian menurun sebanyak $0.06 \mathrm{~cm}$ menjadi $100.60 \pm 9.50 \mathrm{~cm}$. Uji 
Amelia Avissa, Mury Kuswari, Rachmanida Nuzrina, Nazhif Gifari \& Vitria Melani | Pengaruh Program Latihan Olahraga dan Edukasi Gizi Terhadap Komposisi Tubuh, Lingkar Perut dan Lingkar Panggul pada Wanita Usia Produktif di Depok

paired $t$-test menunjukkan bahwa tidak ada perbedaan signifikan $(\mathrm{p}=0.06)$ antara sebelum dan sesudah intervensi olahraga aerobik dan pendidikan gizi dilakukan.

Tabel 5. Analisis Efek Intervensi Terhadap Lingkar Pinggul

\begin{tabular}{|c|c|c|c|}
\hline \multirow{3}{*}{ Variabel } & & & \multirow{3}{*}{$p$-Value } \\
\hline & Sebelum & Sesudah & \\
\hline & \multicolumn{2}{|c|}{ Rataan \pm SD } & \\
\hline Lingkar Pinqqul (cm) & $100.66 \pm 9.53$ & $100.60 \pm 9.50$ & 0.0600 \\
\hline
\end{tabular}

(tidak terdapat perbedaan signifikan)

\section{PEMBAHASAN}

\section{Efek dari Intervensi Terhadap Komposisi Tubuh}

Pengukuran komposisi tubuh, lingkar perut dan lingkar pinggul dilakukan sebelum responden melakukan olahraga dan diulang setiap 2 minggu atau 5 kali pengukuran selama 9 minggu. Perbandingan utama dilihat pada pengukuran 1 dan pengukuran 5; pengukuran 2,3, dan 4 digunakan untuk mengilustrasikan apakah hasil dari setiap pengukuran mengalami peningkatan, penurunan, atau bahkan tidak berubah. Komposisi tubuh yang diukur adalah persentase lemak tubuh dan otot tubuh. Pengukuran ini menggunakan alat Bioelectrical Impedance Analyzes (BIA) GEA Medical EF-981.

Hasil pengukuran komposisi tubuh dapat dilihat pada gambar 1 (persentase lemak tubuh) dan gambar 2 (persentase otot tubuh). Data yang diperoleh menunjukkan bahwa terdapat penurunan persentase lemak tubuh setelah intervensi diberikan. Peningkatan massa otot juga terjadi setelah intervensi diberikan. Hasil ini menunjukkan bahwa peningkatan aktivitas fisik menyebabkan pembakaran simpanan lemak tubuh seimbang dengan kebutuhan energi yang dibutuhkan saat olahraga aerobik. Aktivitas fisik rutin seperti olahraga aerobik dapat memengaruhi komposisi tubuh menjadi lebih baik dan seimbang. Komposisi tubuh terdiri dari otot dan lemak dari berbagai organ lain yang memiliki peranannya masing-masing. Berbagai jenis penyakit dapat timbul karena fungsi organ yang menurun atau kerusakan organ bila komposisi tubuh tidak seimbang. Penelitian Dewi, Kustiyah dan Kuswari (2015) menunjukkan bahwa komposisi lemak tubuh yang tinggi berbanding terbalik dengan kebugaran kardiorespiratorik dan fleksibilitas.

Hasil pengukuran setelah intervensi menunjukan bahwa terjadi penurunan rata-rata lemak tubuh responden sebanyak $0.47 \%$ dan uji paired t-test telah menunjukkan bahwa penurunan ini signifikan $(p<0.05)$ yang menunjukkan bahwa terdapat pengaruh signifikan dari program latihan olahraga dan edukasi gizi terhadap persen lemak tubuh. Uji yang sama juga menunjukkan bahwa massa otot meningkat secara signifikan $(p<0.05)$ sebanyak $0.39 \%$. Hasil ini serupa dengan hasil dari penelitian sebelumnya (Kuswari, Setiawan dan Rimbawan, 2015) bahwa 
terdapat perbedaan signifikan antara lipatan lemak abdominal antara sebelum dan sesudah aktivitas fisik intensitas sedang sebanyak 30 menit/hari. Sehingga, peningkatan level aktivitas fisik dari rekomendasi minimum untuk kesehatan (150 menit/minggu) mungkin dibutuhkan untuk meningkatkan penurunan berat badan jangka panjang (Kuswari, Setiawan dan Rimbawan, 2015)

Studi yang serupa juga menunjukkan bahwa terjadi penurunan dalam persentase lemak tubuh dan peningkatan massa otot setelah intervensi 16 minggu (Guerendiain, Villa-González dan Barranco-Ruiz, 2019). Penelitian tersebut juga menunjukkan bahwa kelebihan lemak tubuh bukan hanya akibat konsumsi lemak semata, tapi terdapat hubungan kompleks antara faktor genetik, olahraga, hormon, dan jenis kelamin. Untuk mendapatkan hasil terbaik dalam penurunan berat badan, direkomendasikan untuk melakukan latihan olahraga aerobik secara rutin (Khatimah, 2020)

Hasil penelitian lain menunjukkan bahwa latihan olahraga aerobik di pusat kebugaran Studio 88 Salatiga terbukti menurunkan berat badan pada $66.78 \%$ responden, persentase lemak tubuh pada $86.42 \%$ responden, dan kadar kolesterol pada $27.67 \%$ responden. Terdapat perbedaan signifikan antara sebelum dan sesudah intervensi olahraga aerobik pada penelitian tersebut terhadap penurunan berat badan, persentase lemak tubuh dan kadar kolesterol pada subjek yaitu remaja perempuan dengan obesitas (Utomo, Junaidi dan Rahayu, 2012). Penelitian ini juga sejalan dengan penelitian pada anggota pusat kebugaran Sumerian Weru Sukoharjo, yakni terdapat pengaruh signifikan antara senam body language dan senam pilates dengan kemampuan bergerak untuk menurunkan persentase lemak tubuh (Hartini, 2016). Menurut penelitian mengenai efek dari intervensi latihan intensif selama 12 minggu dan program diet terhadap komposisi tubuh dan hormon terkait stres pada wanita dengan obesitas, terdapat efek signifikan dari intervensi terhadap antropometri tubuh, komposisi tubuh, asupan makanan, dan kualitas hidup (Chang dan Jung, 2018).

Penelitian pendukung lain yang membahas mengenai efek dari edukasi gizi dan program latihan terhadap indeks obesitas dan modifikasi perilaku pada perempuan dengan obesitas berumur 20-60 tahun selama 12 minggu menunjukkan hasil yang signifikan terhadap penurunan IMT, lingkar perut, dan lemak viseral serta peningkatan massa otot (Chang dan Jung, 2018). Meski begitu, terdapat penelitian lain dengan intervensi yang sama namun hasil yang berbeda. Penelitian dengan intervensi pola makan dan olahraga selama 8 minggu Anam et al. (2016) menghasilkan IMT yang turun dan kebugaran yang meningkat, namun tidak ada efek signifikan terhadap massa lemak. Asupan makanan merupakan variabel yang paling berpengaruh pada penelitian ini. Penelitian serupa Tendean, Pangemanan dan Sapulete (2018) menunjukkan senam zumba yang dilakukan selama 4 minggu dengan frekuensi senam 3 kali per minggu dan durasi 60 menit setiap senam menunjukkan bahwa tidak terdapat perbedaan signifikan antara 
Amelia Avissa, Mury Kuswari, Rachmanida Nuzrina, Nazhif Gifari \& Vitria Melani | Pengaruh Program Latihan Olahraga dan Edukasi Gizi Terhadap Komposisi Tubuh, Lingkar Perut dan Lingkar Panggul pada Wanita Usia Produktif di Depok

lemak tubuh sebelum dan sesudah melakukan senam zumba pada perempuan dewasa.

\section{Efek dari Intervensi Terhadap Lingkar Perut}

Pada usia 30 tahun, metabolisme tubuh menurun yang mengakibatkan lemak terakumulasi secara kontinyu di tubuh karena proses metabolik yang lambat (Astuti, Widyastuti dan Hapsari, 2016). Akumulasi lemak di jaringan seluruh tubuh atau bagian tubuh tertentu seperti perut disebut juga dengan obesitas sentral (Sari, Lipoeto dan Herman, 2016). Hasil pengukuran lingkar perut setelah intervensi menunjukkan penurunan rata-rata lingkar perut sebanyak $0.62 \mathrm{~cm}$ dan hasil ini signifikan setelah diuji dengan paired t-test $(p=0.0001)$ yang mengindikasikan bahawa terdapat pengaruh signifikan dari intervensi gizi dan olahraga terhadap lingkar perut.

Penelitian yang dilakukan mengenai efek dari latihan aerobik terhadap massa otot paha dan kualitas hidup orang dewasa dengan lemak viseral tinggi menunjukkan bahwa berat badan dan lemak viseral menurun secara signifikan setelah intervensi tersebut. Latihan aerobik mengurangi hilangnya massa otot selama fase restriksi energi pada orang dewasa dengan lemak viseral tinggi. Lemak viseral paling banyak ditemukan pada bagian perut, sehingga lemak ini berpengaruh pada lingkar perut (Yoshimura et al., 2014). Penelitian ini sejalan juga dengan penelitian yang dilakukan di pusat kebugaran khusus wanita RM7 yang menunjukkan bahwa terdapat efek signifikan $(p=0.002)$ dari latihan aerobik terhadap lingkar perut perempuan dengan obesitas di pusat kebugaran (Susanti dan Sari, 2017).

Hal ini menunjukkan bahwa program latihan aerobik membuat otot berkontraksi, terutama otot abdominal yang ditemukan di perut. Kontraksi otot dibutuhkan untuk energi, yang dihasilkan oleh pemecahan ATP. Metabolisme energi yang dilakukan selama latihan senam aerobik di Duadua Studio Depok adalah pengolahan ATP. Pengolahan ATP melalui sistem aerobik membutuhkan oksigen untuk memecah glukosa menjadi $\mathrm{CO} 2$ dan $\mathrm{H} 2 \mathrm{O}$. Glukosa atau glikogen dipecah secara kimiawi menajadi asam piruvat dan jika terdapat 02 , asam laktat tidak terakumulasi. Asam piruvat kemudian memasuki siklus Krebs dan rantai transpor elektron, yang menghasilkan $\mathrm{CO} 2$ dan $\mathrm{H} 2 \mathrm{O}$. Proses aerobik ini terjadi di mitokondria sel. Zat yang menjadi bahan bakar ini adalah glikogen (yang menjadi glukosa), lemak dan protein yang mengandung energi potensial yang terikat dalam komposisi dari zat gizi tersebut. Ketika energi potensial ini dilepaskan maka akan berubah menjadi enegri kinetik atau gerak (Rismayanthi, 2015) .

Dalam penelitian ini, jenis latihan aerobik high impact dan low+high impact bertujuan untuk membakar lemak. Ketika olahraga dimulai, energi bersumber dari karbohidrat dan lemak dengan jumlah yang sama. Lambat laun, lemak akan digunakan lebih banyak sebagai bahan bakar energi. Metabolisme karbohidrat memproduksi piruvat yang terbentuk saat kontraksi dan relaksasi. Sumber piruvat ini adalah glikogen yang terdapat di otot atau glukosa darah, yang berubah menjadi glukosa-6-fosfat dan kemudian berubah menjadi asam piruvat. Proses ini 
menghasilkan 8 molekul ATP untuk setiap 1 molekul glukosa. Setelah energi dari glukosa habis, energi kemudian datang dari trigliserida yang terbentuk dari lipolisis adiposa dengan cara mengaktivasi enzim. Asam lemak bebas menyebar dari adiposa ke sirkulasi darah dan berubah menjadi albumin plasma. Asam lemak bebas kemudian dibawa ke jaringan aktif yang kemudian akan diproses secara metabolik menjadi energi. Lemak akan diolah sebagai sumber energi sehingga lambat laun lingkar perut akan menurun karena lemak di daerah perut terbakar menjadi energi ketika melakukan senam aerobik. Pada intensitas sedang, sumber utama energi untuk kontraksi otot adalah karbohidrat dan lemak dengan jumlah yang seimbang (Ratmawati, Pangkahila dan Lesmana, 2013)

Sehingga, dengan melakukan latihan olahraga atau program olahraga seperti senam aerobik dalam jangka panjang dan secara rutin dapat menghasilkan perubahan signifikan pada lingkar perut. Perbedaan dari penelitian ini dengan penelitian sebelumnya adalah peneliti juga memberikan edukasi gizi dalam bentuk konseling dan mini konseling sehingga dapat mengontrol pola makan dan meningkatkan pengetahuan serta memotivasi responden untuk melakukan program yang dijalankan.

\section{Efek dari Intervensi Terhadap Lingkar Pinggul}

Hasil intervensi terhdadap lingkar pinggul menunjukkan terjadinya penurunan pada pengukuran ini sebanyak $0.06 \mathrm{~cm}$. Hasil ini tidak signifikan $(\mathrm{p}=0.060)$ setelah dilakukan uji paired t-test, yang mengindikasikan bahwa tidak ada efek signifikan dari intervensi terhadap penurunan panjang lingkar pinggul. Penelitian yang dilakukan di Aceh menunjukkan bahwa terdapat pengaruh dari aktivitas fisik (latihan aerobik) terhadap IMT $(p=0.000)$ dan tekanan darah $(p=0.000)$ pada perempuan dengan obesitas, namun tidak ada efek signifikan terhadap lingkar pinggul ( $p=0.230$ ) (Fitri et al., 2016). Latihan yoga sebanyak 10 kali pada perempuan dengan berat badan berlebih tidak memiliki efek signifikan terhadap penurunan berat badan, persentase lemak tubuh, lingkar perut, dan rasio lingkar pinggang-pinggul (Fatimah et al., 2018). Meski begitu, penelitian ini tidak sehalan dengan penelitian (Taghian, Zolfaghari dan Hedayati, 2014) dengan intervensi berupa latihan aerobik berat selama 12 minggu, yang menghasilkan penurunan signifikan $(p<0.05)$ terhadap persentase lemak, lingkar pinggul, dan IMT pada kelompok uji bila dibandingkan dengan kelompok kontrol.

Penelitian lain dengan intervensi berupa latihan olaharaga dengan durasi 30 menit, 5 kali per minggu selama 12 minggu menunjukkan penurunan yang signifikan terhadap berat badan, IMT, lingkar pinggul, dan rasio lingkar pinggang-pinggul (Kim, Jung dan Seo, 2014). Penelitian edukasi gizi dalam bentuk konsultasi penurunan berat badan secara langsung dan melalui telfon selama 6 bulan menghasilkan penurunan berat badan yang signifikan. Konsultasi penurunan berat badan ini juga menurunkan lemak tubuh, lingkar pinggang, dan lingkar pinggul secara 
Amelia Avissa, Mury Kuswari, Rachmanida Nuzrina, Nazhif Gifari \& Vitria Melani | Pengaruh Program Latihan Olahraga dan Edukasi Gizi Terhadap Komposisi Tubuh, Lingkar Perut dan Lingkar Panggul pada Wanita Usia Produktif di Depok

signifikan. Berat badan yang turun dicapai melalui aktivitas fisik yang meningkat secara signifikan dan perubahan pada pola makan. Hasil ini menunjukkan bahwa penurunan lingkar pinggul membutuhkan waktu yang lama untuk mencapai hasil yang signifikan (Harrigan et al., 2016).

Hasil dari penelitian lain mengindikasikan bahwa pemberian edukasi taebo diet dan senam taebo memengaruhi status gizi remaja secara signifikan $(p=0.012)$. Uji beda antara kelompok kontrol yang hanya diberi intervensi senam taebo saja dengan kelompok uji yang diberikan intervensi senam taebo dan diet taebo menghasilkan hasil berupa $p=0.027$, yang mengindikasikan bahwa gabungan intervensi senam dan diet lebih efektif dalam menurunkan IMT remaja (Marfu'ah, Nuraeni dan Supriyono, 2017). Pelatihan gizi dan olahraga serta program edukasi pada pasien dengan dementia ringan memberikan peningkatan signifikan pada kondisi gizi sebagai hasil dari edukasi gizi (Cho dan Kim, 2019).

Program latihan atau aktivitas fisik pada perempuan dewasa yang cenderung memiliki gaya hidup sedenter dapat membuat ketidakseimbangan antara energi yang masuk dan keluar tubuh. Keseimbangan energi dapat dicapai apabila energi yang masuk ke tubuh dalam bentuk makanan seimbang dengan energi yang dikeluarkan oleh tubuh. Kelebihan energi dapat terjadi jika konsumsi energi melalui makanan melebihi energi yang dikeluarkan. Kelebihan energi ini akan diubah menjadi lemak tubuh dan berujung pada obesitas. Persentase lemak tubuh akan meningkat seiring bertambahnya usia. Beberapa penelitian di negara berkembang membuktikan bahwa lemak tubuh akan meningkat secara signifikan dalam kurun waktu 30 tahun. Perempuan akan lebih mudah mengalami kenaikan berat badan karena proses kehamilan. Jaringan lemak saat kehamilan akan meningkat dan memiliki dampak terhadap akumulasi asam lemak bebas dalam tubuh (Jati, 2014).

Program olahraga dan gizi pada responden penelitian di pusat kebugaran Duadua Studio Depok memiliki dampak signifikan terhadap komposisi tubuh dan lingkar perut namun tidak memilliki dampak signifikan terhadap lingkar pinggul. Konsultasi gizi atau program edukasi akan menghasilkan peningkatan pengetahuan, kesadaran dan perilaku untuk mencapai kondisi gizi dan kesehatan optimal (Gifari et al., 2018; Nurmasyita et al., 2016). Hal ini secara lebih lanjut akan memengaruhi perilaku seseorang dalam mengonsumsi sumber gizi dalam pangan yang sesuai dengan panduan dan kebutuhan tubuh. Perbaikan pola makan dan aktivitas fisik maupun olahraga adalah cara-cara yang dapat dilakukan dalam menghadapi masalah gizi (Silalahi et al., 2016). Berbagai faktor resiko dapat memicu penyakit tidak menular (PTM), salah satunya adalah kurangnya aktivitas fisik, kelebihan berat badan, dan obesitas. Gaya hidup ini dapat menyebabkan perubahan fisiologis seperti tekanan darah tinggi, glukosa darah tinggi, dan lemak dalam darah tinggi yang secara potensial dapat menyebabkan PTM (Riley et al., 2016). Program latihan olahraga dan edukasi gizi bila dijalankan secara rutin dapat mengurangi masalah obesitas 
maupun PTM yang merupakan masalah global yang memengaruhi masyarakat dunia baik di negara berkembang maupun negara maju termasuk Indonesia.

\section{SIMPULAN}

Program olahraga dan gizi pada responden penelitian di pusat kebugaran Duadua Studio Depok memiliki dampak signifikan terhadap komposisi tubuh dan lingkar perut namun tidak memilliki dampak signifikan terhadap lingkar pinggul. Program latihan olahraga dan edukasi gizi bila dijalankan secara rutin dapat mengurangi masalah obesitas maupun PTM yang merupakan masalah global yang memengaruhi masyarakat dunia baik di negara berkembang maupun negara maju termasuk Indonesia. Dibutuhkan kesadaran responden dalam memantau berat badan secara rutin, meningkatkan aktivitas fisik seperti olahraga dan konsumsi makanan gizi seimbang untuk menjaga komposisi tubuh ideal, lingkar perut, dan lingkar pinggul. Penelitian selanjutnya akan lebih baik jika menggunakan kelompok kontrol dan kelompok uji, sehingga dapat dibandingkan perbedaan antar intervensi.

\section{REFERENSI}

Amanda, N., Nisa, K., dan Tiwuk. (2015). Pengaruh status nutrisi terhadap kebugaran fisik atlit karate di bandar lampung. Jurnal Majority, 4(6), 40-45.

Anam, M., Mexitalia, M., Widjanarko, B., Pramono, A., Susanto, H., dan Subagio, H. W. (2016). Pengaruh intervensi diet dan olah raga terhadap indeks massa tubuh, lemak tubuh, dan kesegaran jasmani pada anak obes. Sari Pediatri. https://doi.org/10.14238/sp12.1.2010.3641

Astuti, H. P., Widyastuti, D. E., dan Hapsari, E. (2016). Pengaruh detoksifikasi mikroba positif pada usus terhadap penurunan berat badan. Jurnal IImiah Rekam Medis Dan Informatika Kesehatan, 6(2).

Barret, K. E., Barman, S. M., Boitano, S., \& Brooks, H. L. (2014). Buku Ajar Fisiologi Kedokteran Ganong. Jakarta: Penerbit Buku Kedokteran EGC.

Chang, M. H., dan Jung, S.J. (2018). Effects of nutrition education and exercise program on obesity index and behavioral modification in moderate obese women. Korean Journal of Community Nutrition, 23(4), 318-332. https://doi.org/10.5720/kjcn.2018.23.4.318

Cho, M. S., \& Kim, J. Y. (2019). Effects of exercise and nutrition education programs on motor function and eating habit in mild dementia patients. Journal of Exercise Rehabilitation. https://doi.org/10.12965/jer.1836632.316

Dewi, M., Kustiyah, L., \& Kuswari, M. (2015). Percent fat mass and body mass index as cardiorespiratory fitness predictors in young adults. Jurnal Gizi Dan Pangan, 10(3). 
Amelia Avissa, Mury Kuswari, Rachmanida Nuzrina, Nazhif Gifari \& Vitria Melani | Pengaruh Program Latihan Olahraga dan Edukasi Gizi Terhadap Komposisi Tubuh, Lingkar Perut dan Lingkar Panggul pada Wanita Usia Produktif di Depok

Fatimah, P. N., Dieny, F. F., Murbawani, E. A., \& Tsani, A. F. A. (2018). Latihan yoga terhadap berat badan, persen lemak tubuh, dan lingkar perut pada wanita dewasa overweight. Jurnal Gizi Klinik Indonesia. https://doi.org/10.22146/ijcn.32150

Fitri, Y., Mulyani, N. S., Fitrianingsih, E., \& Suryana, S. (2016). Pengaruh pemberian aktifitas fisik (aerobic exercise) terhadap tekanan darah, imt dan rlpp pada wanita obesitas. AcTion: Aceh Nutrition Journal. https://doi.org/10.30867/action.v1i2.19

Forbes, G. B. (2000). Body fat content influences the body composition response to nutrition and exercise. Annals of the New York Academy of Sciences. https://doi.org/10.1111/j.17496632.2000.tb06482.x

Gifari, N., Kuswari, M., \& Azza, D. (2018). Pengaruh konseling gizi dan latihan stretching terhadap perubahan asupan gizi dan status gizi. Darrusalam Nutrition Journal, 2(1), 29-40.

Guerendiain, M., Villa-González, E., \& Barranco-Ruiz, Y. (2019). Body composition and dairy intake in sedentary employees who participated in a healthy program based on nutrition education and zumba. Clinical Nutrition. https://doi.org/10.1016/j.clnu.2018.09.032

Hanifah, S. (2015). Artikel e-journal Unesa analisis tingkat VO2max siswa SMA Negeri 1 Balung Kabupaten Jember. Jurnal Kesehatan Olahraga.

Harrigan, M., Cartmel, B., Lofffield, E., Sanft, T., Chagpar, A. B., Zhou, Y., Playdon, M., Li, F., \& Irwin, M. L. (2016). Randomized trial comparing telephone versus in-person weight loss counseling on body composition and circulating biomarkers in women treated for breast cancer: The lifestyle, exercise, and nutrition (LEAN) study. Journal of Clinical Oncology. https://doi.org/10.1200/JCO.2015.61.6375

Hartini. (2016). Perbedaan pengaruh latihan senam body language dan pilates terhadap penurunan persentase lemak tubuh ditinjau dari kemampuan gerak. Jurnal IImiah SPIRIT.

Jati, L. (2014). Perbedaan asupan lemak, lingkar pinggang dan persentase lemak tubuh pada wanita dislipidemia dan non dislipidemia. Jurnal Kesehatan Masyarakat (e-Journal).

Khatimah, K. (2020). Senam aerobik intensitas sedang dan penurunan berat badan, persen lemak serta rasio lingkar pinggang panggul mahasiswa gizi yang overweight. Media Gizi Pangan, 24(1), 57-63.

Kim, D. Y., Jung, S. Y., \& Seo, B. Do. (2014). Effect of exercise intervention on changes in free fatty acid levels and metabolic risk factors in stroke patients. Journal of Physical Therapy Science. https://doi.org/10.1589/jpts.26.275

Kuswari, M., Setiawan, B., \& Rimbawan. (2015). Frekuensi senam aerobik intensitas sedang berpengaruh terhadap lemak tubuh pada mahasiswi IPB. Jurnal Gizi Dan Pangan. https://doi.org/10.25182/jgp.2015.10.1.

Limanan, D. (2013). Hantaran sinyal leptin dan obesitas: hubungannya dengan penyakit kardiovaskuler. E-Journal Kedokteran Indonesia. https://doi.org/10.23886/ejki.1.2063.144155 
Marfu'ah, S., Nuraeni, A., \& Supriyono, M. (2017). Pengaruh edukasi diit dan senam taebo terhadap perubahan status gizi lebih pada remaja di smp negeri 30 semarang. Karya IImiah, $6(1)$.

Nurmasyita, Widjanarko, B., \& Margawati, A. (2016). Pengaruh intervensi pendidikan gizi terhadap peningkatan pengetahuan gizi, perubahan asupan zat gizi dan indeks massa tubuh remaja kelebihan berat badan. Jurnal Gizi Indonesia (The Indonesian Journal of Nutrition). https://doi.org/10.14710/jgi.4.1.38-47

Ratmawati, Y., Pangkahila, A., \& Lesmana, S. I. (2013). Latihan aerobik intensitas sedang dengan diet rendah kolesterol lebih baik dalam memperbaiki kognitif daripada intensitas ringan pada penderita sindroma metabolik. Sport and Fitness Journal.

Riley, L., Guthold, R., Cowan, M., Savin, S., Bhatti, L., Armstrong, T., \& Bonita, R. (2016). The world health organization STEPwise approach to noncommunicable disease risk-factor surveillance: Methods, challenges, and opportunities. American Journal of Public Health. https://doi.org/10.2105/AJPH.2015.302962

Rismayanthi, C. (2015). Sistem energi dan kebutuhan zat gizi yang diperlukan untuk peningkatan prestasi atlet. JORPRES. https://doi.org/10.21831/jorpres.v11i1.10270

Sari, M. K., Lipoeto, N. I., \& Herman, R. B. (2016). Hubungan lingkar abdomen (lingkar perut) dengan tekanan darah. Jurnal Kesehatan Andalas. https://doi.org/10.25077/jka.v5i2.539

Silalahi, V., Aritonang, E., \& Ashar, T. (2016). Potensi pendidikan gizi dalam meningkatkan asupan gizi pada remaja putri yang anemia di kota medan. Jurnal Kesehatan Masyarakat. https://doi.org/10.15294/kemas.v11i2.4113

Suharjana, F. (2013). Perbedaan pengaruh hasil latihan peregangan statis dan dinamis terhadap kelentukan togok menurut jenis kelamin anak kelas 3 dan 4 sekolah dasar. Jurnal Pendidikan Jasmani Indonesia.

Susanti, E., \& Sari, D. R. K. (2017). Pengaruh senam zumba terhadap waist circumference pada wanita obesitas di sanggar senam rm7. Universitas Muhammadiyah Surakarta.

Taghian, F., Zolfaghari, M., \& Hedayati, M. (2014). Effects of aerobic exercise on serum retinol binding protein4, insulin resistance and blood lipids in obese women. Iranian Journal of Public Health.

Tendean, B. A., Pangemanan, D. H. C., \& Sapulete, I. M. (2018). Perbandingan persentase lemak tubuh sebelum dan setelah melakukan senam zumba pada wanita dewasa. Jurnal EBiomedik. https://doi.org/10.35790/ebm.6.2.2018.22110

Utomo, G. T., Junaidi, S., \& Rahayu, S. (2012). Latihan senam aerobik untuk menurunkan berat badan, lemak, dan kolesterol. JSSF (Journal of Sport Science and Fitness).

WHO. (2015). World Health Statistic 2015. In Acta Universitatis Agriculturae et Silviculturae Mendelianae Brunensis.

WHO Regional Office for South-East Asia . (2011). Overweight and obesity. Tersedia pada: URL: http://www.who.int/mediacentre/factsheets/fs311/en/) 
Amelia Avissa, Mury Kuswari, Rachmanida Nuzrina, Nazhif Gifari \& Vitria Melani | Pengaruh Program Latihan Olahraga dan Edukasi Gizi Terhadap Komposisi Tubuh, Lingkar Perut dan Lingkar Panggul pada Wanita Usia Produktif di Depok

Yoshimura, E., Kumahara, H., Tobina, T., Matsuda, T., Ayabe, M., Kiyonaga, A., Anzai, K., Higaki, Y., \& Tanaka, H. (2014). Lifestyle intervention involving calorie restriction with or without aerobic exercise training improves liver fat in adults with visceral adiposity. Journal of Obesity. https://doi.org/10.1155/2014/197216 